\title{
Atypical one-carbon metabolism of an acetogenic and hydrogenogenic Moorella thermoacetica strain
}

\author{
Bo Jiang • Anne-Meint Henstra $\cdot$ Paula L. Paulo $•$ \\ Melike Balk · Wim van Doesburg • Alfons J. M. Stams
}

Received: 16 July 2008 / Revised: 19 September 2008 / Accepted: 24 September 2008 / Published online: 15 October 2008

(C) The Author(s) 2008. This article is published with open access at Springerlink.com

\begin{abstract}
A thermophilic spore-forming bacterium (strain AMP) was isolated from a thermophilic methanogenic bioreactor that was fed with cobalt-deprived synthetic medium containing methanol as substrate. 16S rRNA gene analysis revealed that strain AMP was closely related to the acetogenic bacterium Moorella thermoacetica DSM $521^{\mathrm{T}}$ (98.3\% sequence similarity). DNA-DNA hybridization showed $75.2 \pm 4.7 \%$ similarity to $M$. thermoacetica DSM $521^{\mathrm{T}}$, suggesting that strain AMP is a M. thermoacetica strain. Strain AMP has a unique one-carbon metabolism compared to other Moorella species. In media without cobalt growth of strain AMP on methanol was only sustained in coculture with a hydrogen-consuming methanogen, while in media with cobalt it grew acetogenically in the absence of the methanogen. Addition of thiosulfate led to sulfide formation and less acetate formation. Growth of strain AMP with CO resulted in the formation of hydrogen as the main product, while other CO-utilizing Moorella strains produce acetate as product. Formate supported growth only in the presence of thiosulfate or in coculture with the methanogen. Strain AMP did not grow with $\mathrm{H}_{2}$ / $\mathrm{CO}_{2}$, unlike $M$. thermoacetica $\left(\mathrm{DSM} 521^{\mathrm{T}}\right)$. The lack of
\end{abstract}

Communicated by Wolfang Buckel.

B. Jiang · A.-M. Henstra - M. Balk · W. van Doesburg ·

A. J. M. Stams $(\bowtie)$

Laboratory of Microbiology, Wageningen University, Dreijenplein 10, 6703 HB Wageningen, The Netherlands

e-mail: fons.stams@wur.nl

P. L. Paulo

Department of Hydraulics and Transport,

Federal University of Mato Grosso do Sul,

Cidade Universitária, Campo Grande,

MS 79070-900, Brazil growth with $\mathrm{H}_{2} / \mathrm{CO}_{2}$ likely is due to the absence of cytochrome $b$ in strain AMP.

Keywords Methanol C Carbon monoxide $\cdot$ Formate . Carboxydotrophic $\cdot$ Cobalt limitation $\cdot$ Energy conserving hydrogenase $\cdot$ Homoacetogen $\cdot$ Methanol $\cdot$ Moorella
Abbreviations
CODH Carbon monoxide dehydrogenase
FDH Formate dehydrogenase
$\mathrm{H}_{2}$-ase Hydrogenase
ECH Energy conserving hydrogenase

\section{Introduction}

Carboxydotrophic hydrogenogens are anaerobic bacteria that can grow on carbon monoxide and produce $\mathrm{H}_{2}$ and $\mathrm{CO}_{2}$ as sole products. Carboxydothermus hydrogenoformans was identified as the first strict anaerobic moderately thermophilic bacterium capable of $\mathrm{CO}$ oxidation and $\mathrm{H}_{2}$ evolution (Svetlichny et al. 1991). C. hydrogenoformans produces $\mathrm{H}_{2}$ via a monofunctional $\mathrm{CODH}$, an energy conserving hydrogenase $(\mathrm{ECH})$ and a ferredoxin-like protein $\mathrm{B}$ that mediates electron transfer between $\mathrm{CODH}$ and $\mathrm{ECH}$ (Shelver et al. 1997; Soboh et al. 2002). Carboxydotrophic hydrogenogenic growth is only found in less than ten obligate anaerobic bacteria and one achaeon (see Sipma et al. 2006). Only a few are obligate carboxydotrophic (Svetlichny et al. 1994; Sokolova et al. 2002), while others can also grow heterotrophically on other organic carbon compounds (Pusheva and Sokolova 1995; Sokolova et al. 2001, 2004; Slepova et al. 2006).

Anaerobic growth on $\mathrm{CO}$ has also been described for some so called homoacetogenic bacteria that produce 
acetate and $\mathrm{CO}_{2}$ as products. Among the wide diversity of homoacetogens, spore-forming thermophilic acetogenic bacteria are all members of the genus Moorella (Drake et al. 2008). This genus consists of five validated species and several undescribed strains. Most Moorella species grow on diverse sugars, organic acids, $\mathrm{C} 1$ compounds, including methanol, formate and carbon monoxide, and $\mathrm{H}_{2} /$ $\mathrm{CO}_{2}$. Only M. glycerini is not able to grow on methanol, formate and $\mathrm{H}_{2} / \mathrm{CO}_{2}$ (Slobodkin et al. 1997). Moorella strains can use thiosulfate, and some Moorella strains also use nitrate or perchlorate as electron acceptor for growth (Drake and Daniel 2004; Balk et al. 2008). We describe here the isolation of a spore-forming bacterium (strain AMP) from thermophilic sludge treating methanol-containing wastewater. The bacterium was closest related to Moorella thermoacetica. Strain AMP grew acetogenically on methanol, but grew hydrogenogenically on $\mathrm{CO}$.

\section{Materials and methods}

Source and isolation of microorganisms

Strain AMP was isolated from a methanol-degrading culture that was enriched from thermophilic sludge of a labscale bioreactor (Paulo et al. 2004). The starting material of that reactor was sludge from an anaerobic pilot reactor treating paper mill wastewater first at $40^{\circ} \mathrm{C}$ and later at $55^{\circ} \mathrm{C}$ (Paques BV, Balk, The Netherlands). Methanothermobacter thermautotrophicus strain $\mathrm{NJ} 1$ was isolated from the same enrichment culture (unpublished results). M. thermoacetica DSM $521^{\mathrm{T}}$ was obtained from the Deutsche Sammlung für Mikroorganismen und Zellkulturen (DSMZ, Braunschweig, Germany).

Strains were cultivated in a bicarbonate buffered mineral medium, unless stated otherwise, prepared as described previously (Stams et al. 1993). Vitamin $\mathrm{B}_{12}$, and where indicated $\mathrm{CoCl}_{2}$, was omitted from this medium. Routine cultivation was carried out in $117-\mathrm{mL}$ serum bottles with $50 \mathrm{~mL}$ medium and a $\mathrm{N}_{2} / \mathrm{CO}_{2}(80: 20 \%$, v/v) gas phase at a pressure of $170 \mathrm{kPa}$. $\mathrm{CO}$ or $\mathrm{H}_{2}$ replaced $\mathrm{N}_{2}$ when used as substrate. Methanol $(40 \mathrm{mM})$ was used as sole carbon and energy source for enrichment and isolation. Substrates and electron acceptors were added from neutralized sterile stock solutions to a final concentration of $10 \mathrm{mM}$, unless stated otherwise. To make soft agar media, $8 \mathrm{~g} / \mathrm{L}$ agar (Difco) was added to the medium. Yeast extract and peptone (Difco) were amended at concentrations of $0.2 \mathrm{~g} / \mathrm{L}$, when indicated. For enrichment and isolation incubations were done at $55^{\circ} \mathrm{C}$. Subsequent cultivation experiments were performed at $65^{\circ} \mathrm{C}$. Coculture experiments were performed by inoculating cultures of strain $\mathrm{NJ} 1$ and strain AMP at an inoculum size of $5 \%$ each $(\mathrm{v} / \mathrm{v})$.
Strain AMP was isolated by repeated serial dilutions in liquid methanol-containing media [with addition of $\mathrm{CoCl}_{2}$ $(0.5 \mu \mathrm{M})]$ using an autoclaved $\left(121^{\circ} \mathrm{C}\right.$ for $\left.1 \mathrm{~h}\right)$ culture as inoculum for serial dilutions. The highest dilution with growth was then diluted in soft-agar media. After growth, well-separated colonies were picked, inoculated and diluted in liquid medium with bromoethanesulfonate (Bres, $10 \mathrm{mM})$ and penicillin $\mathrm{G}(2 \mathrm{mg} / \mathrm{mL})$. Cultures were obtained with cells of single type morphology as checked by phase-contrast microscopy. The culture that grew in the highest dilution was designated strain AMP. Purity was confirmed by growth tests in mineral media and in media supplemented with yeast extract and peptone, and in anaerobic Wilkins-Chalgren broth (Oxoid, Basingstoke, UK) amended with thiosulfate and pyruvate.

\section{Physiological characterization}

Electron donor and electron acceptor utilization by strain AMP were tested in the bicarbonate buffered mineral medium (amended with $\mathrm{CoCl}_{2}$ ). Growth on a substrate was confirmed by substrate consumption, product formation, increase in culture turbidity and in most cases subsequent transfers in fresh media. The results presented in the figures and tables are representatives of replicate experiments, and the variations in the measurements were less than $10 \%$. Temperature, salt $(\mathrm{NaCl})$, and $\mathrm{pH}$ optima of growth were analyzed in the bicarbonate buffered mineral medium with methanol $(40 \mathrm{mM})$ as substrate. $\mathrm{pH}$ values in the range from 5.0 to 9.0 were created by the addition of calculated amounts of $1 \mathrm{M} \mathrm{HCl}$ or $1 \mathrm{M} \mathrm{NaOH}$. Cultures were incubated in a temperature range from 37 to $75^{\circ} \mathrm{C}$. Optimal salt concentrations were tested in the range of $10-500 \mathrm{mM}$ $\mathrm{NaCl}$. Gram-staining was performed as described by Gerhardt et al. (1994).

\section{Phylogenetic analysis}

DNA of strain AMP was extracted as described by Zoetendal et al. (1998). The 16S rRNA gene was amplified by PCR using the $7 \mathrm{f}$ and 1492r primer set (Invitrogen, Breda, The Netherlands). Amplified 16S rRNA gene fragments were ligated in pGEM-T Easy vector (manufacturer). Escherichia coli strain JM109 (Promega, Madison, WI, USA) was transformed with the ligation product. Randomly selected colonies of recombinant clones were reamplified by PCR with the vector specific primers $\mathrm{T} 7$ and Sp6 (Promega, Madison, WI, USA). Reamplified DNA fragments were sequenced according to the manufacturer's instructions (Amersham, Slough, United Kingdom) with IRD800-labeled sequencing primer sets Sp6 and T7 (Promega, Madison, WI, USA), 533f and 1100r (Lane 1991). 
Obtained 16S rDNA sequences (1,528 bp) were compared to sequences deposited in the NCBI database (Benson et al. 2004). 16S rRNA gene sequences were aligned using ARB software package (Ludwig et al. 2004). Phylogenetic trees based on $16 \mathrm{~S}$ rRNA gene sequences were constructed using the neighbor-joining method (Saitou and Nei 1987). Bootstrap values were calculated using neighborjoining analysis of 1,000 replicate data sets by SeqBoot and subsequent re-evaluation by DNAPARS, both implemented in the Phylip software package (Felsenstein 1989).

Genomic DNA was isolated according to Visuvanathan et al. (1989) and purified as described (Cashion et al. 1977). The $\mathrm{G}+\mathrm{C}$ content of the genomic DNA was determined at the identification service of the DSMZ (Braunschweig, Germany) by HPLC analysis (Mesbah and Whitman 1989; Tamaoka and Komagata 1984). DNA homology was determined using the reassociation method described by De Ley et al. (1970).

\section{Enzyme assays}

Cells were cultivated on the indicated substrates. Cells were harvested in the late logarithmic phase by centrifugation. Cell-free extracts were prepared by osmotic shock under anoxic conditions and sonication using lysozyme as described previously (Lundie and Drake 1984). Soluble fractions and membrane fractions were obtained by ultracentrifugation of cell-free extracts (Hugenholtz et al. 1987). Carbon monoxide dehydrogenase ( $\mathrm{CODH})$, formate dehydrogenase $(\mathrm{FDH})$ and hydrogenase $\left(\mathrm{H}_{2}\right.$-ase $)$ activities were assayed in $50 \mathrm{mM}$ Tris- $\mathrm{HCl}(\mathrm{pH} 8.5)$ containing benzylviologen (BV, $5 \mathrm{mM}$ ) and dithiothreitol (DTT, $1 \mathrm{mM}$ ) at $55^{\circ} \mathrm{C}$ by using a U2010 spectrophotometer (Hitachi, Japan) as previously described (Hugenholtz et al. 1987). $\mathrm{H}_{2}$-evolution activity $\left(\mathrm{MV}-\mathrm{H}_{2}\right)$ was assayed in $50 \mathrm{mM} \mathrm{MOPS} / \mathrm{KOH}$ buffer at $\mathrm{pH} 7.0$ and $2 \mathrm{mM}$ DTT with reduced methyl viologen (MV, $2 \mathrm{mM}$ ) according to Soboh et al. (2002).

Analytical methods

Organic acids were measured by HPLC as described (Stams et al. 1993). Gases and alcohols were measured by gas chromatography as described (Balk et al. 2003; Henstra and Stams 2004). Nitrate, thiosulfate, and sulfate were analyzed by an HPLC system equipped with an Ionpac AS9SC column and ED40 electrochemical detector (Dionex, Sunnyvale, CA, USA) as described (Scholten and Stams 1995). Cell dry-weights were analyzed as described (Savage and Drake 1986). Sulfide was analyzed by the method of Trüper and Schlegel (1964). To detect the cytochrome $b$, $\mathrm{O}_{2}$-oxidized membrane fractions were reduced by sodium dithionite, and the reduced-minus-oxidized spectra were recorded with a dual-beam spectrophotometer (Hitachi
U2010, Japan) as described by Fröstl et al. (1996). Protein was determined according to the Bradford method with bovine serum albumin as a standard (Bradford 1976).

\section{Results}

Enrichment and isolation

Strain AMP was isolated from a methanol-degrading culture that was initially enriched in laboratory scale anaerobic bioreactors operated at $55^{\circ} \mathrm{C}$ (Paulo et al. 2002, 2004). Further enrichment through serial dilutions in cobalt-free medium resulted in a coculture that consisted of autofluorescent rods and spore-forming rods. Methane was the end product of methanol conversion by that coculture. Serial dilutions of a heat-treated coculture in cobalt-amended agar media resulted in a pure culture of the spore-forming bacterium. Strain AMP has been deposited in the DSMZ (Braunschweig, Germany) as $M$. thermoacetica strain AMP (DSM 21394). Additionally, the methanogenic strain NJ1 was isolated from this coculture by serial dilutions using $\mathrm{H}_{2} / \mathrm{CO}_{2}$ as sole energy and carbon sources. The 16S rRNA gene of strain NJ1 was 99.5\% similar to that of Methanothermobacter thermautotrophicus strain $\Delta \mathrm{H}$. Strain NJ1 was not able to grow with methanol, formate and acetate (results not shown).

Morphology and optimal growth conditions

Strain AMP is a rod shaped, Gram-positive, spore-forming bacterium. Cells of strain AMP grown on methanol were 0.4-1.2 $\mu \mathrm{m}$ wide, and 5-14 $\mu \mathrm{m}$ long (Fig. 1). In old cultures, round swollen terminal endospores were observed. Exponentially growing cells were generally longer than

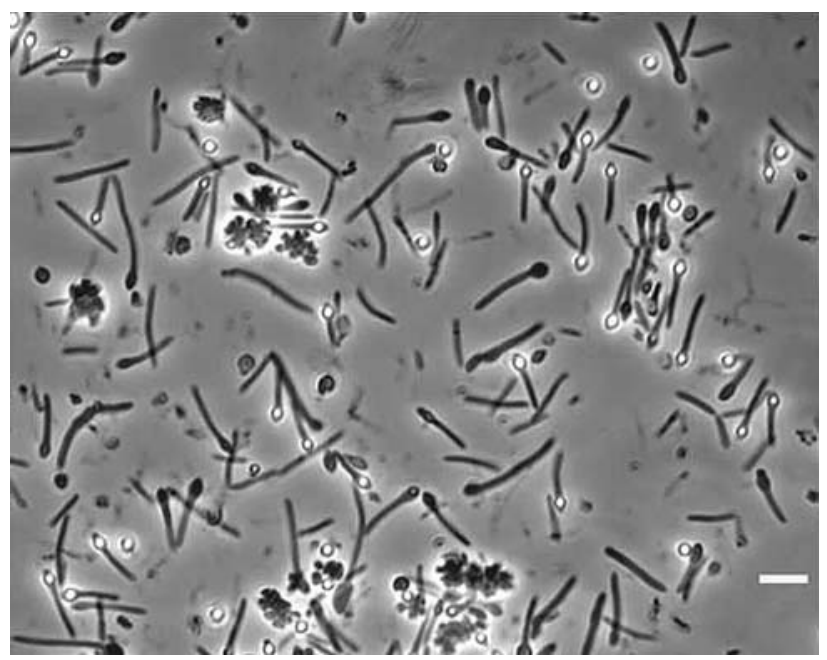

Fig. 1 Phase contrast microscopic picture of strain AMP grown on methanol, showing vegetative cells, sporulating cells and mature spores. Bar indicates $5 \mu \mathrm{m}$ 
sporulating cells. It was observed that immature spores that had a balloon-like appearance, released from cells and disintegrated under exposure of oxygen. Cells were shorter and spores were hardly observed when grown on pyruvate or lactate.

Strain AMP grew at a temperature range of $42-75^{\circ} \mathrm{C}$ with optimal growth between 60 and $65^{\circ} \mathrm{C}$. Growth was observed at a pH of 5.0-8.5 with optimal growth at $\mathrm{pH} 6.9$. Growth rates remained unchanged when $\mathrm{NaCl}$ concentrations were below $150 \mathrm{mM}$. Lower growth rates were observed with $\mathrm{NaCl}$ concentrations of $200 \mathrm{mM}$ and above, while no growth occurred at a $\mathrm{NaCl}$ concentration of $400 \mathrm{mM}$ or higher.

\section{Phylogeny of strain AMP}

The 16S rRNA gene of strain AMP (1,528 bp) was sequenced and is accessible under Genbank accession number AY884087. A neighbor-joining tree based of $16 \mathrm{~S}$ rRNA gene sequences was constructed and indicated that strain AMP fell into the cluster of the genus Moorella (Fig. 2). The similarity of the 16S rRNA gene sequence of strain AMP with other Moorella strains was: M. thermoacetica DSM $521^{\mathrm{T}}(98.3 \%), \quad M$. thermoautotrophica strain DSM1794 (98.2\%), M. glycerini (94.5\%), M. mulderi (91.5\%) and M. perchloratireducens $(97.0 \%)$. The $\mathrm{G}+\mathrm{C}$ content of genomic DNA was $57.3 \mathrm{~mol} \%$. The DNA-DNA hybridisation showed $75.2 \pm 4.7 \%$ (duplicate measurements) similarity with $M$. thermoacetica DSM $521^{\mathrm{T}}$, which is just above the threshold value of $70 \%$ for the definition of species (Wayne et al. 1987)

\section{Substrate utilization}

Strain AMP has a different substrate profile than M. thermoacetica and M. thermoautotrophica (Table 1). It grew on pyruvate, lactate, mannose, methanol $(40 \mathrm{mM})$, vanillate $(5 \mathrm{mM})$, vanillin $(5 \mathrm{mM})$, and $\mathrm{CO} / \mathrm{CO}_{2}$ (headspace, $80: 20 \%, \mathrm{v} / \mathrm{v}, 170 \mathrm{kPa})$. Acetate was the major end product

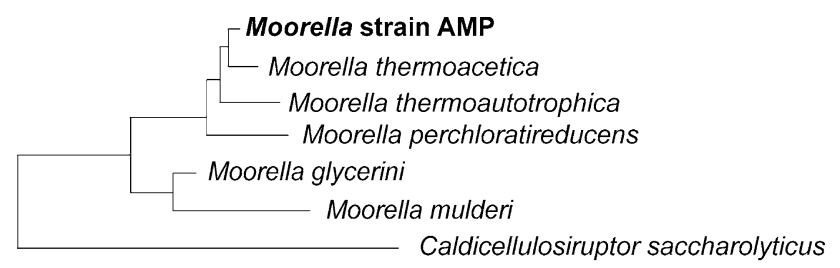

0.10

Fig. 2 Phylogenetic tree based on 16S rRNA gene sequence analysis showing the position of strain AMP within the Moorella genus. The tree was constructed using the neighbor-joining method embedded in ARB package (Saitou and Nei 1987; Ludwig et al. 2004). The bar represents $10 \%$ sequence divergence after growth of strain AMP on these substrates (except on $\mathrm{CO} / \mathrm{CO}_{2}$ ) (Table 2 and data not shown). We did not analyze the formation of aromatic compounds from vanillate and vanillin. The following substrates were tested but not utilized by strain AMP (even not in media amended with yeast extract and peptone): $\mathrm{H}_{2} / \mathrm{CO}_{2}$ (headspace, $80: 20 \%$, v/v, $170 \mathrm{kPa}$ ), acetate, ethanol, $n$-propanol, glycerol, glucose $(5 \mathrm{mM})$, melibiose $(5 \mathrm{mM})$, raffinose $(2 \mathrm{mM})$, rhamnose $(2 \mathrm{mM})$, trehalose $(5 \mathrm{mM})$, arabinose, cellobiose, cellulose, galactose, lactose, maltose, xylose, mannitol, melezitose, ribose $(5 \mathrm{mM})$, sorbitol, starch $(0.5 \mathrm{~g} / \mathrm{L})$, sucrose, and benzoate. Similar to other Moorella species, thiosulfate was used as electron acceptor by strain AMP. This resulted in the formation of sulfide as major product. Strain AMP was only capable of sustained growth with formate and fructose in the presence of thiosulfate. With methanol or lactate as electron donors, nitrate, sulfate, and fumarate were not used as electron acceptors by strain AMP.

Methanol was readily utilized as energy and carbon source by strain AMP (Fig. 3). The ratio of acetate formed to methanol consumed was 0.74 (Table 2). The complete consumption of $40 \mathrm{mM}$ methanol by strain AMP took 6 days at a cobalt concentration of $0.5 \mu \mathrm{M}$. When cobalt was not added, it took more than 16 days to convert the same amount of methanol to acetate (Table 3). In the latter case residual cobalt concentrations were about $0.025 \mu \mathrm{M}$. Repeated transfer in methanol-containing media without cobalt was not possible. Cobalt limitation in cocultures of strain AMP and Methanothermobacter strain NJ1 resulted in more methane and less acetate production (Table 3), but methanol conversion rates were four times lower than in cobalt-amended cocultures. These cocultures could be repeatedly transferred in methanol-containing media without cobalt.

Growth of strain AMP with CO resulted in the formation of $\mathrm{H}_{2}$ as main products (Fig. 4). When grown with $34 \mathrm{kPa}$ $\mathrm{CO}$ the amount of acetate detected was below $0.2 \mathrm{mM}$. Higher $\mathrm{CO}$ conversion rates were observed at higher partial pressures. With 85 and $136 \mathrm{kPa} \mathrm{CO}$ some acetate was detected in the culture liquid, but the concentration never exceeded $2 \mathrm{mM}$. At the end of the incubation the optical density at $600 \mathrm{~nm}$ of the cultures had increased from 0.025 to $0.086(34 \mathrm{kPa}), 0.112(85 \mathrm{kPa})$ and $0.134(136 \mathrm{kPa})$, respectively, indicating that $\mathrm{CO}$ conversion to $\mathrm{H}_{2}$ and $\mathrm{CO}_{2}$ was coupled to growth. This was further confirmed by six successive transfers in fresh mineral medium with $\mathrm{CO}$ as sole energy and carbon source.

As methanol conversion resulted in acetate formation and $\mathrm{CO}$ conversion in hydrogen formation, we also investigated mixed substrate utilization by strain AMP. Figure 3 shows methanol and $\mathrm{CO}$ consumption in cultures inoculated with CO-adapted cells. Production of acetate and consumption of methanol in the culture with methanol and $\mathrm{CO}\left(\mathrm{P}_{\mathrm{CO}}\right.$ 
Table 1 Main characteristics of strain AMP and of phylogenetically related Moorella species

\begin{tabular}{|c|c|c|c|c|c|c|}
\hline & $\begin{array}{l}\text { Strain } \\
\text { AMP }\end{array}$ & M. mulderi & M. glycerini & M. thermoautotrophica & M. thermoacetica & M. perchloratireducens \\
\hline Opt. temp $\left({ }^{\circ} \mathrm{C}\right)$ & 65 & 65 & 58 & $55-58$ & $55-60$ & $55-60$ \\
\hline Opt. pH & 6.9 & 7.0 & $6.3-6.5$ & 5.7 & 6.9 & $6.5-7.0$ \\
\hline $\mathrm{G}+\mathrm{C}$ content of DNA $(\mathrm{mol} \%)$ & 57.3 & 53.6 & 54.5 & $53-55$ & $53-55$ & 57.6 \\
\hline $\begin{array}{l}\% 16 \mathrm{~S} \text { rRNA gene similarity } \\
\text { to strain AMP }\end{array}$ & 100 & 91.5 & 94.5 & 98.2 & 98.3 & 97.0 \\
\hline \multicolumn{7}{|l|}{ Growth substrates } \\
\hline Glucose & - & + & + & + & + & + \\
\hline Fructose & \pm & + & + & + & + & + \\
\hline Pyruvate & + & + & + & + & + & + \\
\hline Lactate & + & + & + & + & - & - \\
\hline Glycerol & - & - & + & - & - & - \\
\hline Methanol & + & + & - & + & + & + \\
\hline Formate & $t^{\mathrm{a}}$ & + & - & + & \pm & - \\
\hline $\mathrm{H}_{2} / \mathrm{CO}_{2}$ & - & + & - & + & + & - \\
\hline $\mathrm{CO} / \mathrm{CO}_{2}$ & $+\left(\right.$ to $\left.\mathrm{H}_{2}\right)$ & ND & ND & $+($ to acetate $)$ & $+($ to acetate $)$ & $+($ to acetate $)$ \\
\hline \multicolumn{7}{|l|}{ Electron acceptors } \\
\hline Nitrate & - & - & - & + & + & + \\
\hline Thiosulfate & + & + & + & + & + & + \\
\hline Perchlorate & - & + & + & - & \pm & + \\
\hline Fumarate & - & - & + & - & - & - \\
\hline
\end{tabular}

Characteristics of other Moorella species were obtained from Balk et al. (2003), Fontaine et al. (1942), Wiegel et al. (1981), Slobodkin et al. (1997) and Balk et al. (2008) supplemented with data in Drake and Daniel (2004)

$N D$ not detected

${ }^{a}$ Growth only in the presence of an electron acceptor.,+- or \pm indicates that growth is positive, negative, weak or less reproducible growth, respectively

Table 2 Single and mixed substrate utilization by strain AMP in the presence and absence of thiosulfate as electron acceptor

\begin{tabular}{|c|c|c|c|c|c|c|c|c|c|c|c|}
\hline \multirow{2}{*}{$\begin{array}{l}\text { First substrate } \\
(\mathrm{mM}) \text { consumed }\end{array}$} & \multirow{2}{*}{$\begin{array}{l}\text { Second } \\
\text { substrate }(\mathrm{mM}) \\
\text { consumed }\end{array}$} & \multirow{2}{*}{$\begin{array}{l}\mathrm{S}_{2} \mathrm{O}_{3}{ }^{2-} \\
\text { addition } \\
(\mathrm{mM})\end{array}$} & \multirow{2}{*}{$\begin{array}{l}\text { Biomass mg dry } \\
\text { weight/mol C of } \\
\text { the first substrate }\end{array}$} & \multicolumn{4}{|c|}{ Products $(\mathrm{mM})$} & \multicolumn{2}{|c|}{ Recovery } & \multirow{2}{*}{$\begin{array}{l}\text { Acetate/ } \\
\text { substrate }^{\mathrm{d}} \\
\text { (measured) }\end{array}$} & \multirow{2}{*}{$\begin{array}{l}\text { Acetate/ } \\
\text { substrate } \\
\text { (theoretical) }\end{array}$} \\
\hline & & & & Acetate & $\mathrm{H}_{2}^{\mathrm{a}}$ & $\mathrm{HS}^{-}$ & $\overline{\text { Formate }}$ & {$[\mathrm{H}] \%^{b}$} & $\overline{\mathrm{C} \%}{ }^{\mathrm{c}}$ & & \\
\hline Methanol (38.7) & - & - & 2.84 & 27.7 & 0.1 & ND & 1.8 & 84 & 98 & 0.74 & 0.75 \\
\hline Methanol (39.2) & $\operatorname{CO}\left(108.3^{\mathrm{a}, \mathrm{e}}\right)$ & - & 3.82 & 36.2 & 60.2 & ND & 0.4 & 93 & 94 & 1.09 & 1.00 \\
\hline Methanol (39.8) & - & 20 & 4.77 & 17.9 & 0.5 & 3.2 & ND & 107 & 76 & 0.56 & 0 \\
\hline Methanol (39.4) & Formate (48.3) & - & 4.82 & 31.8 & 1.8 & ND & NA & 81 & 85 & 1.02 & 1.0 \\
\hline CO (116) & - & - & 0.78 & 1.9 & 92 & ND & 2.0 & 97 & 93 & 0.02 & 0.25 \\
\hline CO (113) & - & 20 & 1.19 & 0.2 & 62.9 & 0.7 & 3.1 & 81 & 99 & 0.002 & 0 \\
\hline Formate (53.0) & CO (30) & - & 1.69 & 9.9 & 20.4 & ND & NA & 89 & 79 & 0.21 & 0.25 \\
\hline Formate (47.4) & - & 20 & 3.56 & 8.8 & 2.4 & 3.0 & NA & 85 & 105 & 0.20 & 0 \\
\hline Lactate (16.5) & - & - & 3.49 & 17.4 & 1.6 & ND & 0.3 & 104 & 99 & 1.23 & 1.50 \\
\hline Lactate (16.4) & $\mathrm{CO}(34.5)$ & - & 2.68 & 20.3 & 14.5 & ND & 4.9 & 86 & 97 & 1.55 & 1.67 \\
\hline Lactate (16.5) & - & 20 & 2.36 & 17 & 1.3 & 4.2 & 0.4 & 115 & 104 & 1.13 & 0 \\
\hline
\end{tabular}

A methanol-grown culture was used as inoculum for all the incubations

- no addition, $N D$ measured but not detected, $N A$ not applicable

${ }^{a}$ Expressed in $\mathrm{mM}(\mathrm{mmol} / \mathrm{L}$ medium)

${ }^{\mathrm{b}}$ Electrons produced were calculated using available electrons in the products and substrate based on half reactions

${ }^{c} \mathrm{CO}_{2}$ was estimated based on the stoichiometry of the reaction

${ }^{\mathrm{d}}$ Calculated after correction for the amount of carbon incorporated into biomass

${ }^{\mathrm{e}} \mathrm{CO}$ at around 110 and $30 \mathrm{mmol} / \mathrm{L}$ corresponds to 136 and $34 \mathrm{kPa}$, respectively 


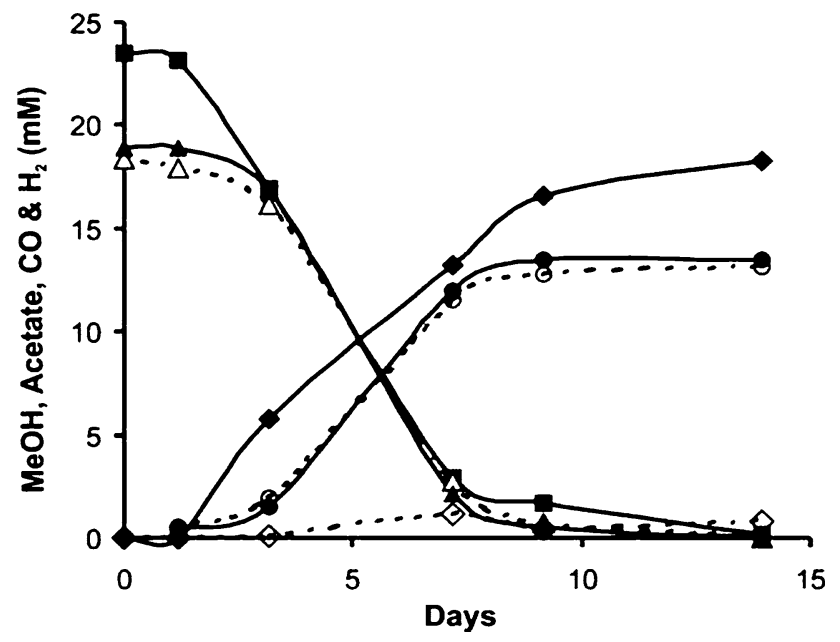

Fig. 3 Conversion of methanol $(20 \mathrm{mM})$ in the presence and absence of $\mathrm{CO}(34 \mathrm{kPa})$ by strain AMP. Methanol; dashed lines and open symbols. Methanol and $\mathrm{CO}$; solid lines and closed symbols. Acetate open circle, filled circle; methanol open triangle, filled triangle; $\mathrm{CO}$ filled square; and $\mathrm{H}_{2}$ filled diamond, open diamond

$34 \mathrm{kPa}$ ) were similar as with methanol alone. In addition, $\mathrm{H}_{2}$ was produced stoichiometrically from CO. However, when methanol-adapted cultures were incubated with methanol in the presence of $136 \mathrm{kPaCO}$, more acetate was formed. In that case, the ratio acetate formed to methanol consumed became 1.09 (Table 2). This resulted in less hydrogen formation. $\mathrm{CO}$ conversion coupled to hydrogen formation also occurred in cultures of strain AMP that were amended with pyruvate, lactate or formate, and when thiosulfate was used as electron acceptor (Table 2). Higher ratios of acetate produced to substrate consumed were measured in cultures with pyruvate or lactate and a $\mathrm{CO}$ containing gas phase, while $\mathrm{H}_{2}$ was also formed (data not shown and Table 2).

Formate dehydrogenase, $\mathrm{H}_{2}$-ase, $\mathrm{CODH}$ and $\mathrm{H}_{2}$-evolution activities were analyzed in cell-free extracts prepared from cells grown on methanol and methanol/CO. Specific activities of FDH of methanol- and methanol/CO-grown cells were about $3 \mathrm{U}$ (mg protein $)^{-1} \cdot \mathrm{H}_{2}$-ase levels decreased from 28 to $9 \mathrm{U}$ (mg protein) ${ }^{-1}$ and CODH levels increased from 60 to $92 \mathrm{U}$ (mg protein $)^{-1}$ when cells grew on methanol in the presence of CO. The difference in the spectrum of reduced versus oxidized membranes obtained from both methanol and methanol/CO grown cells showed no absorption peak around 430 and $560 \mathrm{~nm}$, indicating that cytochrome $b$ was not present in the cell membrane fractions. Similarly, we could not detect cytochrome $b$ peaks in the cytoplasmic fraction. This suggests that cytochrome $b$ is lacking in strain AMP. Control experiments with $M$. thermoacetica DSM $521^{\mathrm{T}}$ confirmed that the type strain did contain b-type cytochromes.

Fast growth and formate conversion were observed when strain AMP was inoculated in mineral medium with formate and thiosulfate (Fig. 5). In these cultures $3 \mathrm{mM}$ sulfide, $3.4 \mathrm{mmol} \mathrm{L}^{-1} \mathrm{H}_{2}(4,750 \mathrm{~Pa})$ and $8.1 \mathrm{mM}$ acetate were formed from $47.5 \mathrm{mM}$ formate in 16 days (Fig. 5, Table 2). Formate did not support growth when thiosulfate was absent or replaced by sulfate, nitrate or fumarate. However, formate was utilized as a cosubstrate during growth on methanol (Table 2). In the absence of thiosulfate, hydrogen gradually built up to a partial pressure of $2,000 \mathrm{~Pa}$ in 40 days. Removal of hydrogen by replacing the headspace resulted again in a hydrogen built up to 2,000 $\mathrm{Pa}$. As shown recently a coculture of strain AMP and the hydrogen-utilizing strain NJ1 grows syntrophically in mineral media with formate as sole energy and carbon substrate (Dolfing et al. 2008).

\section{Discussion}

Previously, a syntrophic methanol-degrading enrichment culture was obtained by using cobalt limited mineral media (Paulo et al. 2004). An obligate hydrogenotrophic methanogen, strain $\mathrm{NJ} 1$, and the methanol-utilizing strain AMP described here were isolated from this enrichment. This coculture resembled the first described syntrophic methanol-degrading coculture (previously thought to be a pure culture, Methanobacillus kuzneceovii), that consisted of $M$. thermoautotrophica strain Z-99 and Methanobacterium thermoformicicum strain Z-245, but this coculture was enriched at a high cobalt concentration of $540 \mu \mathrm{M}$ (Pantskhava and Pchelkina 1969). In our experiments incubations in cobalt sufficient $(0.5 \mu \mathrm{M})$ media resulted in the enrichment and isolation of methylotrophic methanogen Methanomethylovorans thermophila (Jiang et al. 2005). The effect
Table 3 The effect of cobalt and Methanothermobacter thermautotrophicus strain $\mathrm{NJ} 1$ on methanol conversion by strain AMP

\begin{tabular}{lllllll}
\hline $\begin{array}{l}\text { Micro- } \\
\text { organism(s) }\end{array}$ & $\begin{array}{l}\mathrm{Co}^{2+} \\
\text { addition }\end{array}$ & $\begin{array}{l}\text { Methanol } \\
\text { consumed } \\
(\mathrm{mM})\end{array}$ & $\begin{array}{l}\text { Days required } \\
\text { to consume } \\
\text { methanol }\end{array}$ & \multicolumn{2}{l}{ Main products } \\
\cline { 5 - 7 } & & 41 & 5 & $\begin{array}{l}\text { Acetate } \\
(\mathrm{mM})\end{array}$ & $\begin{array}{l}\mathrm{CH}_{4} \\
(\mathrm{mmol} / \mathrm{L})\end{array}$ & $\begin{array}{l}\mathrm{H}_{2} \\
(\mathrm{mmol} / \mathrm{L})\end{array}$ \\
\hline Strain AMP & + & 40 & 16 & 30 & - & 0.9 \\
& - & 42 & 7 & 29 & - & 4.6 \\
Strain AMP + & + & 42 & 30 & 20 & 6.4 & $<0.01$ \\
strain NJ1 & - & 4 & 2.2 & 28 & 0.4 \\
\hline
\end{tabular}




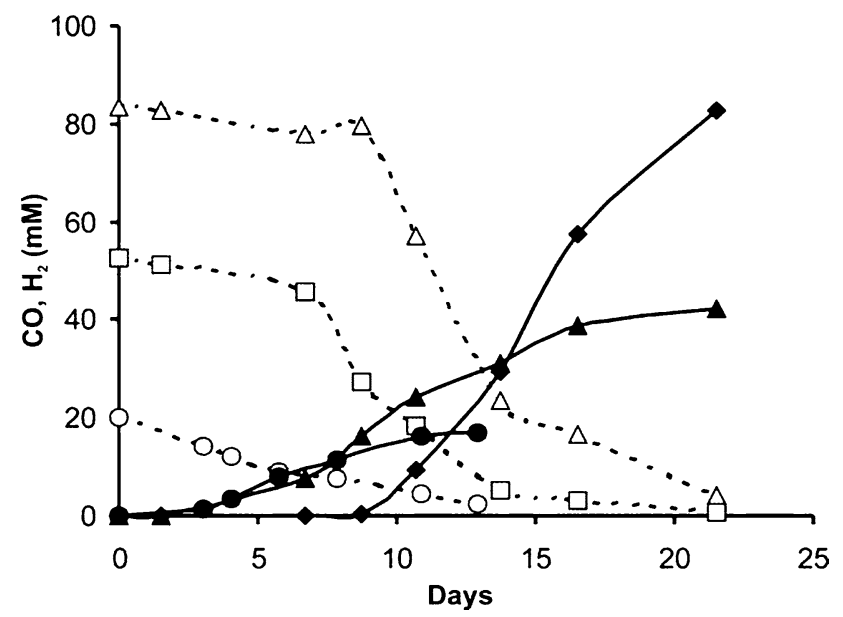

Fig. 4 Conversion of 20, 50 and 80\% CO (dashed lines, open symbols) by strain AMP coupled to $\mathrm{H}_{2}$ formation (solid lines and closed symbols). $20 \%\left(\mathrm{P}_{\mathrm{CO}} 34 \mathrm{kPa}\right)$ (filled circle, open circle); 50\% ( $\mathrm{P}_{\mathrm{CO}}$ $85 \mathrm{kPa})$ (filled triangle, open square); $80 \%\left(\mathrm{P}_{\mathrm{CO}} 136 \mathrm{kPa}\right)$ (filled diamond, open triangle) $\mathrm{CO}$

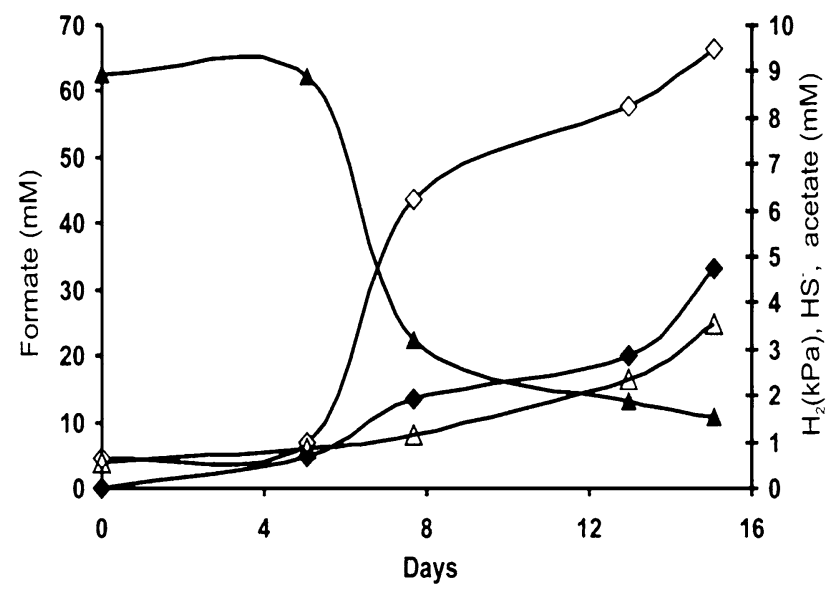

Fig. 5 Formate conversion by strain AMP in the presence of $20 \mathrm{mM}$ thiosulfate as electron acceptor. Formate filled triangle; Acetate open diamond; $\mathrm{H}_{2}$ filled diamond; $\mathrm{HS}^{-}$open triangle

of cobalt on growth of strain AMP is not exactly clear. We assume that in the presence of cobalt strain AMP like other acetogenic bacteria employs a corrinoid-containing methyltransferase for methanol degradation (Daas et al. 1996; Stupperich and Konle 1993; Drake and Daniel 2004). The cofactor-bound methyl group will become the methyl group of acetate in the acetyl-CoA pathway. It might be that methanol dehydrogenase is involved in the oxidation of methanol in the absence of cobalt, resulting in the formation of formaldehyde which cannot enter the acetyl-CoA pathway, but which can be oxidized to $\mathrm{CO}_{2}$. In M. thermoautotrophica a methanol dehydrogenase with pyrroloquinoline quinone as the prosthetic group is present (Winters and Ljungdahl 1989), which is an indication that such an enzyme might also exist in strain AMP.
Strain AMP is an acetogen as indicated by substrate to product ratios, the presence of $\mathrm{CODH}$ and its phylogeny (Drake et al. 2002). However, unlike many other acetogens strain AMP cannot grow acetogenically on $\mathrm{H}_{2} / \mathrm{CO}_{2}$ or formate, although strain AMP could grow on formate in the presence of thiosulfate. Growth of Moorella and Sporomusa species on $\mathrm{H}_{2} / \mathrm{CO}_{2}$ or formate depends on the activity of $\mathrm{H}_{2}$-ase and $\mathrm{FDH}$ and the presence of a membrane electron transport chain that comprises cytochrome $b$ for energy conservation (Kuhner et al. 1997; Ljungdahl 1994). $\mathrm{H}_{2}$-ase and FDH activities were detected in strain AMP, but cytochrome $b$ was not found. The absence of cytochrome $b$ may explain why strain AMP cannot grow acetogenically on $\mathrm{H}_{2} /$ $\mathrm{CO}_{2}$ or formate. A cytochrome $b$-deficient mutant of Sporomusa sphaeroides BK824 (Kamlage and Blaut 1993) and M. thermoacetica (Fröstl et al. 1996) that fails to express cytochrome $b$ in the presence of nitrate, were also not able to grow on these substrates in the basal media. In Acetobacterium woodii and Thermoanaerobacter kivui energy is conserved in a sodium ion gradient, in a pathway that does not involve cytochrome $b$ (Müller and Gottschalk 1994). Apparently, such an alternative pathway is lacking in strain AMP. Acetate is produced as a main product when strain AMP is grown on formate plus $\mathrm{CO}$ or formate plus thiosulfate (Table 2). This suggests that the acetyl-CoA pathway in strain AMP is fully functional for acetate and/or biomass synthesis. We speculate that the bacterium is not able to conserve energy in the acetyl-CoA pathway and that energy conservation takes place in other ways, like thiosulfate respiration or as discussed below by an ECH.

Strain AMP produced high amounts of hydrogen during growth on $\mathrm{CO}$ (Fig. 5, Table 2). When $\mathrm{CO}$ was the sole substrate hydrogen was formed stoichiometrically according to: $\mathrm{CO}+\mathrm{H}_{2} \mathrm{O} \rightarrow \mathrm{CO}_{2}+\mathrm{H}_{2}\left(\Delta \mathrm{G}^{\mathrm{o} \prime}=-20 \mathrm{~kJ}\right)$, indicating carboxydotrophic hydrogenogenic growth of strain AMP. M. thermoacetica also produced high amounts of hydrogen in the presence of $\mathrm{CO}$ during growth on glucose (Martin et al. 1983). However, in this strain hydrogen was not derived from $\mathrm{CO}$ oxidation, since in the absence of glucose no hydrogen was formed from CO. It was speculated that in M. thermoacetica $\mathrm{CO}$ just acted as an inhibitor of the CODH-acetyl CoA synthetase (ACS) complex, which resulted in a shift from acetate formation to hydrogen formation (Kellum and Drake 1984). It was concluded that this hydrogen production did not result in energy conservation (Drake et al. 2002; Kellum and Drake 1984). Hydrogen was also produced when strain AMP grew on CO plus lactate, $\mathrm{CO}$ plus methanol and $\mathrm{CO}$ plus formate (Table 2), suggesting that both bifunctional and monofunctional $\mathrm{CODH}$ are present in strain AMP. These complexes seem to function simultaneously or separately depending on the substrates that are provided. The monofunctional CODH in conjunction with an ECH results in a proton gradient across 
the cytoplasmic membrane that is the driving force for ATP synthesis as shown for $C$. hydrogenoformans growing on CO (Shelver et al. 1997; Soboh et al. 2002).

Strain AMP is a physiologically atypical M. thermoacetica strain. Unlike most Moorella strains strain AMP is not able to grow fermentatively on glucose, $\mathrm{H}_{2} / \mathrm{CO}_{2}$ and formate. Similar to M. mulderi and M. glycerini (Slobodkin et al. 1997), strain AMP is unable to use nitrate as electron acceptor. In contrast to M. glycerini, strain AMP is unable to grow on glycerol and unable to reduce fumarate (Table 1). Like M. thermoacetica, M. thermoautotrophica and M. perchloratireducens strain AMP could grow on CO, but the end product is $\mathrm{H}_{2}$ rather than acetate, which is the main end product of the other three Moorella species. Thus, strain AMP is the first bacterium within the Moorella genus that shows hydrogenogenic growth. The property of strain AMP to dispose reducing equivalents as hydrogen results in a dependence of hydrogen-consuming methanogens when grown on formate or on methanol, when cobalt is limiting. The conversions formate ${ }^{-}+\mathrm{H}^{+} \rightarrow \mathrm{H}_{2}+\mathrm{CO}_{2}\left(\Delta \mathrm{G}^{\mathrm{O} \prime}=-4 \mathrm{~kJ}\right)$ and methanol $+\mathrm{H}_{2} \mathrm{O} \rightarrow 3 \mathrm{H}_{2}+\mathrm{CO}_{2}\left(\Delta \mathrm{G}^{\prime \prime}=+17 \mathrm{~kJ}\right)$ can only result in energy conservation when the hydrogen partial pressure is kept low. Further comparative studies are needed to elucidate the similarities and differences of strain AMP and the type strain of $M$. thermoacetica. The available genome sequence of $M$. thermoacetica DSM $521^{\mathrm{T}}$ may be very useful in this respect (Pierce et al. 2008).

Acknowledgments We are grateful to Sonja Parshina for fruitful discussions. This work was supported by the Netherlands Technology Foundation STW, applied science division of NWO and the technology program of the Ministry of Economic Affaires of the Dutch government, under the project WWL4928.

Open Access This article is distributed under the terms of the Creative Commons Attribution Noncommercial License which permits any noncommercial use, distribution, and reproduction in any medium, provided the original author(s) and source are credited.

\section{References}

Balk M, Weijma J, Friedrich MW, Stams AJM (2003) Methanol utilization by a novel thermophilic homoacetogenic bacterium, Moorella mulderi sp. nov., isolated from a bioreactor. Arch Microbiol 179:315-320

Balk M, Weelink S, van Gelder T, Stams AJM (2008) (Per)chlorate reduction by the thermophilic bacterium, Moorella perchloratireducens sp. nov., isolated from an underground gas storage. Appl Environ Microbiol 74:403-409

Benson DA, Karsch-Mizrachi I, Lipman DJ, Ostell J, Wheeler DL (2004) GenBank: update. Nucleic Acids Res 32(Database issue):D23-D26

Bradford MM (1976) A rapid and sensitive method for the quantitation of microgram quantities of protein utilizing the principle of protein-dye binding. Anal Biochem 72:248-254

Cashion P, Holder-Franklin MA, McCully J, Franklin M (1977) A rapid method for the base ratio determination of bacterial DNA. Anal Biochem 81:461-466
Collins MD, Lawson PA, Willems A, Cordoba JJ, Fernandez-Garayzabal J, Garcia P, Cai J, Hippe H, Farrow JA (1994) The phylogeny of the genus Clostridium: proposal of five new genera and eleven new species combinations. Int J Syst Bacteriol 44:812-826

Daas PJH, Wassenaar RW, Willemsen P, Theunissen RJ, Keltjens JT, van der Drift C, Vogels GD (1996) Purification and properties of an enzyme Involved in the ATP-dependent activation of the methanol:2-mercaptoethanesulfonic acid methyltransferase reaction in Methanosarcina barkeri. J Biol Chem 271:22339_ 22345

De Ley J, Cattoir H, Reynaerts A (1970) The quantitative measurement of DNA hybridization from renaturation rates. Eur $\mathrm{J}$ Biochem 12:133-142

Dolfing J, Jiang B, Henstra AM, Stams AJM, Plugge CM (2008) Syntrophic growth on formate: a new microbial niche in anoxic environments. Appl Environ Microbiol 74:6126-6131

Drake HL, Daniel SL (2004) Physiology of the thermophilic acetogen Moorella thermoacetica. Res Microbiol 155:869-883

Drake HL, Gössner AS, Daniel SL (2008) Old acetogens, new light. Ann N Y Acad Sci 1125:100-128

Drake HL, Küsel K, Matthies C (2002) Ecological consequences of the phylogenetic and physiological diversities of acetogens. Antonie Van Leeuwenhoek 81:203-213

Felsenstein J (1989) PHYLIP—phylogeny inference package (version 3.2). Cladistics 5:164-166

Fontaine FE, Peterson WH, McCoy E, Johnson MJ, Ritter GJ (1942) A new type of glucose fermentation by Clostridium thermoaceticum n. sp. J Bacteriol 43:701-715

Fröstl JM, Seifritz C, Drake HL (1996) Effect of nitrate on the autotrophic metabolism of the acetogens Clostridium thermoautotrophicum and Clostridium thermoaceticum. J Bacteriol 178:4597-4603

Gerhardt P, Murry RGE, Wood WA, Krieg NR (1994) Methods for general and molecular bacteriology. American Society for Microbiology, Washington DC, pp 31-32

Henstra AM, Stams AJM (2004) Novel physiological features of Carboxydothermus hydrogenoformans and Thermoterrabacterium ferrireducens. Appl Environ Microbiol 70:7236-7240

Hugenholtz J, Ivey DM, Ljungdahl LG (1987) Carbon monoxide-driven electron transport in Clostridium thermoautotrophicum membranes. J Bacteriol 169:5845-5847

Jiang B, Parshina SN, van Doesburg W, Lomans BP, Stams AJM (2005) Methanomethylovorans thermophila sp. nov., a thermophilic methylotrophic methanogen from an anaerobic reactor fed with methanol. Int J Syst Evol Microbiol 55:2465-2470

Kamlage B, Blaut M (1993) Isolation of a cytochrome-deficient mutant strain of Sporomusa sphaeroides not capable of oxidizing methyl groups. J Bacteriol 175:3043-3050

Kellum R, Drake HL (1984) Effects of cultivation gas phase on hydrogenase of the acetogen Clostridium thermoaceticum. J Bacteriol 160:466-469

Kuhner CH, Frank C, Griesshammer A, Schmittroth M, Acker G, Gossner A, Drake HL (1997) Sporomusa silvacetica sp, nov., an acetogenic bacterium isolated from aggregated forest soil. Int $\mathbf{J}$ Syst Bacteriol 47:352-358

Lane DJ (1991) 16S/23S rRNA sequencing. In: Stackebrandt E, Goodfellow M (eds) Nucleic acid techniques in bacterial systematics. Wiley, New York, pp 115-175

Ljungdahl LG (1994) The acetyl-CoA pathway and the chemiosmotic generation of ATP during acetogenesis. In: Drake HL (ed) Acetogenesis. Chapman \& Hall, New York, pp 63-87

Ludwig W, Strunk O, Westram R, Richter L, Meier H, Yadhukumar, Buchner A, Lai T, Steppi S, Jobb G, Forster W, Brettske I, Gerber S, Ginhart AW, Gross O, Grumann S, Hermann S, Jost R, Konig A, Liss T, Lussmann R, May M, Nonhoff B, Reichel B, Strehlow R, Stamatakis A, Stuckmann N, Vilbig A, Lenke M, Ludwig T, 
Bode A, Schleifer KH (2004) ARB: a software environment for sequence data. Nucleic Acids Res 32:1363-1371

Lundie LL, Drake HL (1984) Development of a minimally defined medium for the acetogen Clostridium thermoaceticum. J Bacteriol 159:700-703

Martin DR, Lundie LL, Kellum R, Drake HL (1983) Carbon monoxide-dependent evolution of hydrogen by the homoacetate-fermenting bacterium Clostridium thermoaceticum. Curr Microbiol $8: 337-340$

Mesbah M, Whitman WB (1989) Measurement of deoxyguanosine/ thymidine ratios in complex mixtures by high-performance liquid chromatography for determination of the mole percentage guanine + cytosine of DNA. J Chromatogr 479:297-306

Müller V, Gottschalk G (1994) The sodium ion cycle in acetogenic and methanogenic bacteria: generation and utilization of a primary electrochemical sodium ion gradient. In: Drake HL (ed) Acetogenesis. Chapman \& Hall, New York, pp 127-156

Pantskhava ES, Pchelkina VV (1969) Methane fermentation of methanol by a Methanobacillus kuzneceovii culture. Prikladnaya Biokhimiya Mikrobiologiya 5:416-420

Paulo PL, Jiang B, Cysneiros D, Stams AJM, Lettinga G (2004) Effect of cobalt on the anaerobic thermophilic conversion of methanol. Biotechnol Bioeng 85:434-441

Paulo PL, Jiang B, Roest K, van Lier JB, Lettinga G (2002) Start-up of a thermophilic methanol-fed UASB reactor: change in sludge characteristics. Water Sci Technol 45(10):145-150

Pierce E, Xie G, Barabote RD, Saunders E, Han CS, Detter JC, Richardson P, Brettin TS, Das A, Ljungdahl LG, Ragsdale SW (2008) The complete genome sequence of Moorella thermoacetica (f. Clostridium thermoaceticum). Environ Microbiol 10:2550-2573

Pusheva MA, Sokolova TG (1995) Distribution of CO-dehydrogenase activity in anaerobic thermophilic carboxydotrophic bacterium Carboxydothermus hydrogenoformans grown at the expense of $\mathrm{CO}$ or pyruvate. Mikrobiologiya 64:581-586

Saitou N, Nei M (1987) The neighbor-joining method: a new method for reconstructing phylogenetic trees. Mol Biol Evol 4:406-425

Savage MD, Drake HL (1986) Adaptation of the acetogen Clostridium thermoautotrophicum to minimal medium. J Bacteriol 165:315318

Scholten JC, Stams AJM (1995) The effect of sulfate and nitrate on methane formation in a freshwater sediment. Antonie Van Leeuwenhoek 68:309-315

Shelver D, Kerby RL, He Y, Roberts GP (1997) CooA, a CO-sensing transcription factor from Rhodospirillum rubrum, is a CO-binding heme protein. Proc Natl Acad Sci USA 94:11216-11220

Sipma J, Henstra AM, Parshina SM, Lens PN, Lettinga G, Stams AJM (2006) Microbial CO conversions with applications in synthesis gas purification and bio-desulfurization. Crit Rev Biotechnol 26:41-65

Slepova TV, Sokolova TG, Lysenko AM, Tourova TP, Kolganova TV, Kamzolkina OV, Karpov GA, Bonch-Osmolovskaya EA (2006) Carboxydocella sporoproducens sp. nov., a novel anaerobic COutilizing $/ \mathrm{H}_{2}$-producing thermophilic bacterium from a Kamchatka hot spring. Int J Syst Evol Microbiol 56:797-800

Slobodkin A, Reysenbach AL, Mayer F, Wiegel J (1997) Isolation and characterization of the homoacetogenic thermophilic bacterium Moorella glycerini sp. nov. Int J Syst Bacteriol 47:969-974

Soboh B, Linder D, Hedderich R (2002) Purification and catalytic properties of a $\mathrm{CO}$-oxidizing: $\mathrm{H}_{2}$-evolving enzyme complex from
Carboxydothermus hydrogenoformans. Eur J Biochem 269:5712-5721

Sokolova TG, Gonzalez JM, Kostrikina NA, Chernyh NA, Tourova TP, Kato C, Bonch-Osmolovskaya EA, Robb FT (2001) Carboxydobrachium pacificum gen. nov., sp. nov., a new anaerobic, thermophilic, CO-utilizing marine bacterium from Okinawa Trough. Int J Syst Evol Microbiol 51:141-149

Sokolova TG, Kostrikina NA, Chernyh NA, Slepova TV, Bonch-Osmolovskaya EA, Gonzalez JM, Robb FT (2004) Thermosinus carboxydivorans gen. nov., sp. nov., a new anaerobic, thermophilic, carbon-monoxide-oxidizing, hydrogenogenic bacterium from a hot pool of Yellowstone National Park. Int J Syst Evol Microbiol 54:2353-2359

Sokolova TG, Kostrikina NA, Chernyh NA, Tourova TP, Kolganova TV, Bonch-Osmolovskaya EA (2002) Carboxydocella thermautotrophica gen. nov., sp. nov., a novel anaerobic, CO-utilizing thermophile from a kamchatkan hot spring. Int J Syst Evol Microbiol 52:1961-1967

Stams AJM, van Dijk JB, Dijkema C, Plugge CM (1993) Growth of syntrophic propionate-oxidizing bacteria with fumarate in the $\mathrm{ab}$ sence of methanogenic bacteria. Appl Environ Microbiol 59:1114-1119

Stupperich E, Konle R (1993) Corrinoid-dependent methyl transfer reactions are involved in methanol and 3, 4-dimethoxybenzoate metabolism by Sporomusa ovata. Appl Environ Microbiol 59:3110-3116

Svetlichny VA, Sokolova TG, Gerhardt M, Ringpfeil M, Kostrikina NA, Zavarzin GA (1991) Carboxydothermus hydrogenoformans gen. nov., sp. nov., a CO-utilizing thermophilic anaerobic bacterium from hydrothermal environments of Kunashir Island. Syst Appl Microbiol 14:254-260

Svetlichny VA, Sokolova TG, Kostrikina NA, Lysenko AM (1994) Carboxydothermus restrictus sp. nov. a new thermophilic anaerobic carboxydotrophic bacterium. Mikrobiologiya 63:523-528

Tamaoka J, Komagata K (1984) Determination of DNA base composition by reversed-phase high-performance liquid chromatography. FEMS Microbiol Lett 25:125-128

Trüper HG, Schlegel HG (1964) Suphur metabolism in Thiorhodaceae. I. Quantitative measurements on growing cells of Chromatium okenii. Antonie Van Leeuwenhoek 30:225-238

Visuvanathan S, Moss MT, Stanford JL, Hermon-Taylor J, McFadden JJ (1989) Simple enzymic method for isolation of DNA from diverse bacteria. J Microbiol Methods 10:59-64

Wayne LG, Brenner DJ, Colwell RR, Grimont PAD, Kandler O, Krichevsky MI, Moore LH, Moore WEC, Murray RGE, Stackebrandt E, Starr MP, Trüper HG (1987) Report of the ad hoc committee on reconciliation of approaches to bacterial systematics. Int J Syst Bacteriol 37:463-464

Wiegel J, Braun M, Gottschalk G (1981) Clostridium thermoautotrophicum species novum, a thermophile producing acetate from molecular hydrogen and carbon dioxide. Curr Microbiol 5:255-260

Winters DK, Ljungdahl LG (1989) PQQ-dependent methanol dehydrogenase from Clostridium thermoautotrophicum. In: Jongejan JA, Duine JA (eds) PQQ and quinoproteins. Kluwer, Dordrecht, pp 35-39

Zoetendal EG, Akkermans ADL, de Vos WM (1998) Temperature gradient gel electrophoresis analysis of $16 \mathrm{~S}$ rRNA from human fecal samples reveals stable and host-specific communities of active bacteria. Appl Environ Microbiol 64:3854-3859 